\title{
Exploring the Use of Educational Technology among Deaf Students in the United Arab Emirates
}

\author{
Abdoulaye Kaba*, Ziyad K. Ellala \\ College of Education, Humanities \& Social Science, Al Ain University, UAE
}

Received July 20, 2020; Revised August 17, 2020; Accepted September 29, 2020

\section{Cite This Paper in the following Citation Styles}

(a): [1] Abdoulaye Kaba, Ziyad K. Ellala, "Exploring the Use of Educational Technology among Deaf Students in the United Arab Emirates," Universal Journal of Educational Research, Vol. 8, No. 10, pp. 4845 - 4852, 2020. DOI: 10.13189/ujer.2020.081056.

(b): Abdoulaye Kaba, Ziyad K. Ellala (2020). Exploring the Use of Educational Technology among Deaf Students in the United Arab Emirates. Universal Journal of Educational Research, 8(10), 4845 - 4852. DOI: 10.13189/ujer.2020.081056.

Copyright $\subseteq 2020$ by authors, all rights reserved. Authors agree that this article remains permanently open access under the terms of the Creative Commons Attribution License 4.0 International License

\begin{abstract}
This paper reported the findings of a case study conducted about the use of educational technology among deaf students. The paper explored gender and academic major differences of deaf students in using the computer and the Internet. Data was collected through a survey questionnaire. The participants were 38 deaf students, 18 males and 20 females, studying the Special Education and Applied Sociology programs at Al Ain University (AAU). The collected data were analyzed using frequency distributions, averages, and t-test. The findings of the study confirmed significant differences among participants to concerning gender and academic major. The differences were significant in using the computer as a thinking tool for problem-solving and the ability to use software related to the courses. Likewise, the findings of the study confirmed significant differences among students in using the Internet for accessing information, to upload files and assignments, and to improve knowledge. These findings suggest the impact of gender and academic major on the use of computer and the Internet among deaf students. The paper could be an important reference to understand how deaf students use educational technology, particularly computer and the Internet, for educational activities.
\end{abstract}

Keywords Educational Technology, Gender, Academic Major, Deaf Students, Computer, The Internet

\section{Introduction}

The last decade of the twentieth century and the beginning of the twenty-first century witnessed tremendous progress in the field of technology in general, and information and communication technologies in particular, and this affected political, social, cultural and educational systems [5]. One of the beneficiaries of this progress has been the persons with disabilities. The progress opened new horizons for people with disabilities and gave them a lot of freedom in their lives [2, 4].

Educational technologies are defined as scientific tools, programs and products that convey the educational message and vision to learners in order to attain the desired educational goals [21]. Instructional technologies for people with special needs are modified or customized to increase their competencies and performance [1]. Belson [2] noted that the use of instructional technology reduces the gap between individuals with a disability and normal students. According to Male [3], technology makes a person with a disability an effective learner. Jones, MacArthur, and Akaygün [4] reported how educational technologies can be used to engage students in the learning process.

Interest in the use of technologies in the educational process has become a modern trend. This is because most of the people believe in the feasibility of these techniques and the positive effects on the achievement of educational goals, as well as enabling generations to keep pace with the requirements of the age of information awareness and 
cognitive explosion and technological development [18].

As a productive institution of science and knowledge, the university cannot be isolated from what it knows. The world of evolution and progress is rather demanding more openness to scientific and technological achievements in the world to enable its graduates to accomplish a certain level that allows keeping pace with global changes [19]. University students are the community's hope for progress in all aspects of life. They have the responsibility to challenge and overcome various difficulties. They are the first lanes of human resources in all institutions. Therefore, universities are mandated to ensure that these students are intellectually and psychologically prepared to achieve the hope of their communities, and maybe self-effectiveness. The creative and supra-cognitive thinking share of this setting, which may be reflected on creativity and innovation in various institutions especially that the work now is the work of thought and creativity [6].

The Convention on the Rights of Persons with Disabilities has emphasized the empowerment of persons with disabilities use of technology, methods and means of communication, and in environments that enable maximum academic and social growth [7]. The percentage of deaf individuals is estimated at $0.6 \%$ of the community. The UAE is endeavouring to provide all services and programs suitable for the deaf and hard of hearing. The UAE Ministry of Education integrates and educates all children with special needs [8]. They include deaf students in all stages of education up to the undergraduate level, and students share with other ordinary students, special education in obtaining educational opportunities available when needed. The team also works to develop students on the scope of physical and mental health, maintain and realize economic well-being through access to educational and professional opportunities, and participation after the formal study period [8].

Certainly, deaf people have the ability to learn and use ICT tools and resources for education, employment, and social interactions. They use digital information resources for reading, writing and social interaction, through their visual sense and auditory residues $[9,10,11]$. Prior studies have investigated the use of ICT tools and resources among deaf people from a different part of the world.

A study by Pilling and Barrett [12] on the preferences of deaf people with different communication tools show that deaf people used a variety of communication channels such as electronic mails (Emails) and short messaging systems (SMS). Barak and Sadovsky [13] reported about the Internet characteristics, severity and types of use by deaf adolescents compared to the hearing participants. The results of the study indicated that deaf participants used the Internet more often than hearing participants. Besides, deaf people used the Internet for communication more than the hearing participants did. Peddie and Kelly-Campbell [14] conducted a study to understand the use of the Internet among deaf people. Findings revealed that deaf people used the Internet to identify and use the needed information.

Al Ain University (AAU), in 2015 became the first-ever university in the United Arab Emirates (UAE) to offer bachelor degrees in Special Education and Applied Sociology for deaf students [10]. The programs started with 30 Deaf students in Al Ain and 38 students in Abu Dhabi. The implementation follows careful planning and coordination with potential partners.

AAU has been keen to use modern technologies in the educational process in its curricula and educational plans as a basis for innovation and innovation to prepare the students for the job market. Therefore, the university has paid great attention to the use of modern technologies. The colleges are connected to the highest speed of the Internet and provide classrooms with various materials and electronic devices. Electronic courses are also provided on the university website equipped with learning technologies such as Microsoft Team, Moodle, and Egate.

Our review of the literature identified many studies conducted about deaf people in UAE [10, 15, 16]. However, most of these studies reported medical aspects of deafness, engineering aspects of deafness, and deaf people at primary and elementary schools. There is a need for conducting more studies about deaf people in universities and colleges. The current study explores the computer and the Internet use of deaf students of AAU.

The main question to answer in this paper is why and for what purpose deaf students use the computer and the Internet. Besides, the current study verifies and validates if:

a). There is a significant gender difference among deaf students in using the computer and the Internet for educational activities.

b). There is a significant academic difference among deaf students in using the computer and the Internet for educational activities.

The findings of the study should shed light on understanding the use of computer and the Internet by deaf students for educational purpose. The results of the study could be useful in designing and planning ICT related training for deaf students.

\section{Research Method}

The main purpose of this study is to explore and investigate the use of educational technology among deaf students. The paper is based on quantitative research design method and addresses the use of computer and the Internet for educational activities among deaf students at Al Ain University.

The research instrument, a survey questionnaire, was prepared to answer the above research questions. The design of the instrument was based on previous related studies about the use of educational technology among deaf students [17]. The questionnaire consisted of eight items 
measuring computer use and seven items measuring Internet use. The sample of the study consisted of all 38 deaf students at Al Ain University, majoring in the Special Education program and Applied Sociology program. The participants received the print questionnaire in the classrooms. The collected data were analyzed using Microsoft Excel and Statistical Package for the Social Science (SPSS). Frequency distributions, averages, and statistical tests were performed to answer research questions and achieve research objectives. Responses to the statements were rated "Low" if the mean score is between 0.00-1.00, "Moderate" if the mean score is between 1.01-2.00, and "High" if the mean score is above 2.00. Table 1 shows the distribution of participants in the study.

Table 1. The participants

\begin{tabular}{|c|c|c|c|}
\hline \multirow{2}{*}{ Gender } & \multicolumn{2}{|c|}{ Academic Major } & \multirow{2}{*}{ Total } \\
\cline { 2 - 3 } & $\begin{array}{c}\text { Special } \\
\text { Education }\end{array}$ & Applied Sociology & \\
\hline Male & 14 & 4 & 18 \\
\hline Female & 4 & 16 & 20 \\
\hline Total & 18 & 20 & 38 \\
\hline
\end{tabular}

\section{Findings}

As stated earlier, in this study the use of educational technology refers to the use of computer and the Internet by deaf students. The following sections explain the use of computers and the Internet by deaf students for educational activities.

\subsection{Computer Use}

As presented in Table 2, respondents were asked to express their use of the computer through eight statements. On the first statement, male deaf students appeared using a computer for improving language and correction writing mistakes (Average $=2.44$ ) than female students (Average $=$ 2.40). Similarly, deaf students majoring in applied sociology seems to have better use of computer for language improvement and correcting writing mistakes (Average $=2.60)$ than deaf students majoring in Special Education (Average $=2.22$ ). However, the analyses of Independent t-test indicate no significant difference between male and female students ( $t$ value $=0.187$, $p$-value $=0.683$ ) and between students majoring in special education and those majoring in applied sociology (t value $=-1.648$, $\mathrm{p}$-value $=0.108$ ). These findings indicate that gender and academic major have no effect on the use of computer improving language and correcting writing mistakes.

On the second statement, female deaf students seem to use the computer for improving thinking and focus (Average $=2.55$ ) as compared to male deaf students
(Average $=2.16$ ). Likewise, deaf students majoring in applied sociology are found to have better use of computer for thinking and focus (Average $=2.70$ ) than deaf students majoring in special education (Average $=2.00$ ). Moreover, the Independence t-test results show that the difference between males and females is not significant (t value $=$ -1.529, p-value $=0.135$ ) but significant between students majoring in special education and students majoring in applied sociology ( $\mathrm{t}$ value $=-3.030$, $\mathrm{p}$-value $=0.005$ ). The findings indicate that unlike gender academic major may have an impact on the use of computer for thinking and focus among deaf students.

On the third statement, female students appeared more confident in using computer programs without attending formal training (Average $=2.10$ ) than male deaf students (Average $=2.00$ ). Similarly, deaf students majoring in Special Education seem to have more ability to use computer programs without attending formal training (Average $=2.0556$ ) than students majoring in Applied Sociology (Average $=2.0500$ ). However, the Independent t-test indicates that these differences are not significant (p-value more than 0.05). The findings confirm that gender and academic major have no impact on the students' ability to use the computer without attending formal training.

On the fourth statement, male deaf students are found to improve their computer skills during their free times (Average $=2.27$ ) as compared to female deaf students (Average $=2.25$ ). On the other hand, deaf students majoring in Special Education spent more free times for improving computer skills (Average $=2.238$ ) than the students majoring in Applied Sociology (Average $=2.225$ ). However, the Independent $\mathrm{t}$-test indicates that these differences are not significant (p-value more than 0.05).

On the fifth statement, male deaf students appeared helping their colleagues in solving computer-related problems (Average $=2.66$ ) than female students (Average $=2.15$ ). Likewise, deaf students majoring in Special Education help their colleagues in solving computer-related problems (Average: 2.66) than the students majoring in Applied Sociology (Average $=2.15$ ). Moreover, the Independent t-test indicates that the differences are significant between males and females and between Special Education and Applied Sociology (p-value less than 0.05).

On the sixth statement, female deaf students reported using more computers for assignments and innovative presentations (1.95) than male students (1.77). On the other hand, deaf students majoring in Applied Sociology reported using computers for assignments and presentation (Average: 1.90) than the students of Special Education (Average: 1.83). However, the Independent t-test indicates that the differences are not significant ( $\mathrm{p}$-value more than 0.05).

On the seventh statement, respondents expressed their wiliness to use the computer whenever possible. To be more specific, male students are found keener to do that 
(Average: 2.00) than female students (Average $=1.95$ ). Similarly, deaf students majoring in Special Education are found keener to use computer anytime (Average: 2.00) as compared to students majoring in Special Education (Average: 1.90) than the students of (Average: 1.83). However, the Independent t-test indicates that the differences are not significant (p-value more than 0.05).

On the eight statements, students believed that they can use all computer software needed for their courses. However, male deaf students appeared more confident about this statement (Average: 2.77) than the female students (Average: 2.25). Likewise, deaf students majoring in Special Education seems to be more confident about this statement (Average: 2.77) than the students majoring in Applied Sociology (Average $=2.25$ ). Moreover, the Independent t-test indicates that the differences are significant between males and females and between Special Education and Applied Sociology (p-value less than 0.05).

Table 2. Computer Use by Deaf Students

\begin{tabular}{|c|c|c|c|c|c|}
\hline Sta.* & Gender / Academic Major & $\mathbf{N}$ & Average & t- value & P-value \\
\hline \multirow{4}{*}{1} & Male & 18 & 2.4444 & \multirow{2}{*}{0.187} & \multirow{2}{*}{0.683} \\
\hline & Female & 20 & 2.4000 & & \\
\hline & Special Education & 18 & 2.2222 & \multirow{2}{*}{-1.648} & \multirow{2}{*}{0.108} \\
\hline & Applied Sociology & 20 & 2.6000 & & \\
\hline \multirow{4}{*}{2} & Male & 18 & 2.1667 & \multirow{2}{*}{-1.529} & \multirow{2}{*}{0.135} \\
\hline & Female & 20 & 2.5500 & & \\
\hline & Special Education & 18 & 2.0000 & \multirow{2}{*}{-3.030} & \multirow{2}{*}{$0.005^{*}$} \\
\hline & Applied Sociology & 20 & 2.7000 & & \\
\hline \multirow{4}{*}{3} & Male & 18 & 2.0000 & \multirow{2}{*}{-0.497} & \multirow{2}{*}{0.622} \\
\hline & Female & 20 & 2.1000 & & \\
\hline & Special Education & 18 & 2.0556 & \multirow{2}{*}{0.028} & \multirow{2}{*}{0.978} \\
\hline & Applied Sociology & 20 & 2.0500 & & \\
\hline \multirow{4}{*}{4} & Male & 18 & 2.2778 & \multirow{2}{*}{0.131} & \multirow{2}{*}{0.81} \\
\hline & Female & 20 & 2.2500 & & \\
\hline & Special Education & 18 & 2.3889 & \multirow{2}{*}{1.146} & \multirow{2}{*}{0.259} \\
\hline & Applied Sociology & 20 & 2.1500 & & \\
\hline \multirow{4}{*}{5} & Male & 18 & 2.6667 & \multirow{2}{*}{2.693} & \multirow{2}{*}{$0.011^{*}$} \\
\hline & Female & 20 & 2.1500 & & \\
\hline & Special Education & 18 & 2.6667 & \multirow{2}{*}{2.693} & \multirow{2}{*}{$0.011^{*}$} \\
\hline & Applied Sociology & 20 & 2.1500 & & \\
\hline \multirow{4}{*}{6} & Male & 18 & 1.7778 & \multirow{2}{*}{-0.748} & \multirow{2}{*}{0.459} \\
\hline & Female & 20 & 1.9500 & & \\
\hline & Special Education & 18 & 1.8333 & דבר & ᄀ 700 \\
\hline & Applied Sociology & 20 & 1.9000 & 0.257 & 0.799 \\
\hline & Male & 18 & 2.0000 & م & ז7 \\
\hline 7 & Female & 20 & 1.9500 & -0.288 & 0.775 \\
\hline 1 & Special Education & 18 & 2.0000 & 0257 & 700 \\
\hline & Applied Sociology & 20 & 1.9500 & 0.257 & 0.799 \\
\hline & Male & 18 & 2.7778 & סרזתר & $0010 *$ \\
\hline 8 & Female & 20 & 2.2500 & 2.528 & $0.016^{*}$ \\
\hline 0 & Special Education & 18 & 2.7778 & סכ-2 & $0010 *$ \\
\hline & Applied Sociology & 20 & 2.2500 & 2.528 & $0.016^{*}$ \\
\hline
\end{tabular}

$P$-value is significant at 0.05 (two-tailed). *Statements: 1 = I use a computer for improving my language and correction writing mistakes. $2=I$ use a computer to improve my thinking and focus. $3=$ I can use new computer programs without attending formal training. $4=$ I use my free times to improve my computer skills. $5=$ I help my colleagues in solving computer-related problems. $6=$ I use a computer to prepare assignments and innovative presentations. $7=$ I am keen to use the computer whenever possible. $8=$ I can use all computer software related to my courses. 


\subsection{The Internet Use}

Like computer use, we explored Internet use among deaf students through seven statements (Table 3). Responses to the first statement confirm the Internet use among deaf students as a self-learning or self-teaching tool. The analysis of mean scores indicates that male deaf students are more likely to use the Internet for this purpose (Average Use $=2.72$ ) as compared to female deaf students (Average Use $=2.50$ ). Similarly, deaf students majoring in Applied Sociology are found using the Internet as a self-learning and teaching tool (Average Use $=2.70$ ) than other deaf students majoring in Special Education (Average Use $=2.50$ ). . Nevertheless, the Independent t-test results revealed that the usage differences related to gender or major are not significant (p-value more than 0.05 . The findings indicate that both gender and the academic major of deaf student do not affect the use of the Internet as a tool for self-learning or self-teaching.

Responses to the second statement confirm high use of the Internet among deaf students to access course-related information. As presented in Table, male deaf students appeared to use the Internet more for this purpose (Average use $=2.55$ ) than the female deaf students (Average Use $=$ 2.150). Likewise, the average score of deaf students majoring in Special Education (Average Use $=2.55$ ) is higher than that of students from Applied Sociology (Average Use $=2.150$ ). Moreover, the analysis of Independent t-test confirms a significant difference among students based on their gender or major (p-value less than 0.05 ). These findings indicate that gender, as well as the major of the deaf student, may have an impact on the use of the Internet to access course-related information.

On the third statement, the results of the study confirm high use of the Internet as a tool for improving thinking skills among students. Male deaf students recorded the high use of the Internet for this purpose (Average use = 2.50 ) than the female deaf students (Average Use $=2.40$ ). Similarly, the average use is higher among deaf students majoring in Special Education (Average Use $=2.61$ ) than that of students from Applied Sociology (Average Use = 2.30). However, the analysis of the Independent t-test confirms that the difference among the students concerning gender or academic major is not significant (p-value more than 0.05 ). This means the gender and academic major of a deaf student do not have an impact on the use of the Internet for improving thinking skills.

Responses to the fourth statement show that the majority of students use the Internet to upload assignments and files. Male deaf students recorded high use of the Internet for this purpose (Average use $=2.55$ ) than the female deaf students (Average Use $=2.05$ ). Similarly, the average use is higher among deaf students majoring in Special Education (Average Use $=2.72$ ) than that of students from Applied Sociology (Average Use $=1.90$ ). On the other hand, the analysis of the Independent t-test confirms that the differences among the students in relation to gender or academic major are significant (p-value less than 0.05). This means the gender or academic major of the deaf student may have an effect on the use of the Internet to upload assignment and files.

On the use of the Internet as a source of knowledge, the fifth statement (Table 3), male and Special Education students recorded the highest average use of the Internet to improve their knowledge (Average Use $=2.11$ ) as compared to moderate average use among female and Applied Sociology students (Average Use $=1.50$ ). Moreover, the analysis of the Independent t-test confirms that the differences among the students concerning gender and academic major are significant (p-value less than 0.05). This means the gender or academic major of a deaf student may affect the use of the Internet for improving knowledge.

On the use of the Internet for educational activities, the sixth statement (Table 3), participants reported a moderate average use. However, male deaf students appeared using the Internet for educational activities (Average Use $=1.94$ ) more as compared to female students (Average Use $=1.80$ ). Likewise, students majoring in Special Education registered better use (Average Use $=1.88$ ) than those students majoring in Applied Sociology (Average Use = 1.85). It is noteworthy to know that, the results of the Independent t-test confirm that the gender or academic major differences among deaf students are not significant. This means gender and academic major have no impact on the use of the Internet for educational activities among deaf students.

On the use of the Internet for sharing information, the seventh statement (Table 3), respondents reported moderate average use. Males deaf students appeared sharing more information through the Internet using the Internet (Average Use $=1.72$ ) than female students (Average Use $=1.60$ ). On the other hand, students majoring in Applied Sociology recorded better use (Average Use $=1.80$ ) than students of Special Education (Average Use $=1.50$ ). However, the analysis of the Independent t-test confirms that gender or academic major differences among deaf students are not significant. This means gender and academic major have no impact on the use of the Internet for sharing information with colleagues. 
Table 3. The Internet Use by Deaf Students

\begin{tabular}{|c|c|c|c|c|c|}
\hline Sta.* & Gender / Academic Major & $\mathrm{N}$ & Average & t-value & $\mathrm{p}$-value \\
\hline \multirow{4}{*}{1} & Male & 18 & 2.7222 & \multirow{2}{*}{1.399} & \multirow{2}{*}{0.171} \\
\hline & Female & 20 & 2.5000 & & \\
\hline & Special Education & 18 & 2.5000 & \multirow{2}{*}{-1.252} & \multirow{2}{*}{0.219} \\
\hline & Applied Sociology & 20 & 2.7000 & & \\
\hline \multirow{4}{*}{2} & Male & 18 & 2.5556 & \multirow{2}{*}{2.832} & \multirow{2}{*}{$0.008^{*}$} \\
\hline & Female & 20 & 2.1500 & & \\
\hline & Special Education & 18 & 2.5556 & \multirow{2}{*}{2.832} & \multirow{2}{*}{$0.008 *$} \\
\hline & Applied Sociology & 20 & 2.1500 & & \\
\hline \multirow{4}{*}{2} & Male & 18 & 2.5000 & \multirow{2}{*}{0.506} & \multirow{2}{*}{0.616} \\
\hline & Female & 20 & 2.4000 & & \\
\hline & Special Education & 18 & 2.6111 & \multirow{2}{*}{1.627} & \multirow{2}{*}{0.113} \\
\hline & Applied Sociology & 20 & 2.3000 & & \\
\hline \multirow{4}{*}{4} & Male & 18 & 2.5556 & \multirow{2}{*}{2.380} & \multirow{2}{*}{$0.023^{*}$} \\
\hline & Female & 20 & 2.0500 & & \\
\hline & Special Education & 18 & 2.7222 & \multirow{2}{*}{4.495} & \multirow{2}{*}{$0.000^{*}$} \\
\hline & Applied Sociology & 20 & 1.9000 & & \\
\hline \multirow{4}{*}{5} & Male & 18 & 2.1111 & \multirow{2}{*}{4.335} & \multirow{2}{*}{$0.000^{*}$} \\
\hline & Female & 20 & 1.5000 & & \\
\hline & Special Education & 18 & 2.1111 & \multirow{2}{*}{4.335} & \multirow{2}{*}{$0.000^{*}$} \\
\hline & Applied Sociology & 20 & 1.5000 & & \\
\hline \multirow{4}{*}{6} & Male & 18 & 1.9444 & \multirow{2}{*}{0.543} & \multirow{2}{*}{0.593} \\
\hline & Female & 20 & 1.8000 & & \\
\hline & Special Education & 18 & 1.8889 & \multirow{2}{*}{0.146} & ת08 \\
\hline & Applied Sociology & 20 & 1.8500 & & 0.885 \\
\hline & Male & 18 & 1.7222 & 0 & 0 \\
\hline 7 & Female & 20 & 1.6000 & 0.526 & 0.002 \\
\hline 1 & Special Education & 18 & 1.5000 & 17 & $10 r$ \\
\hline & Applied Sociology & 20 & 1.8000 & $-1.31 /$ & 0.196 \\
\hline
\end{tabular}

P-value is significant at 0.05 (two-tailed). *Statement: $1=I$ use the Internet for self-learning or teaching. $2=I$ use the Internet to access information related to my major. $3=$ I use the Internet to improve my thinking skills. $4=$ I use the Internet to upload files and assignments. $5=I$ always use Internet websites related to my courses to improve my knowledge. $6=$ I use the Internet for educational activities. $7=$ I use the Internet for sharing information with my colleagues.

\section{Discussion}

This study has investigated the use of educational technology among deaf students. The paper has explored the use of computer and the Internet for an educational purpose among 38 deaf students. The high use of the computer by the participants is recorded for improving language skills, writing skills, and thinking skills. These findings are in line with Maiorana-Basas and Pagliaro study [20] in which deaf people were found using computers for educational purpose. Meanwhile, the majority of respondents reported the ability to use the computer without formal training, have the ability to help colleagues in solving computer-related problems, have the ability to use needed computer software, and spend free times to improve computer skills. These high uses by deaf students could be related to the course curricula and learning outcomes that encourage the use of computer among deaf students enrolled in the Special Education and Applied Sociology programs.

Another possibility is the level of computer literacy skills among students. This is because the high level of computer literacy skills may result in high use of the computer as educational tools. Similarly, low computer literacy skills may result in low use of computer for the educational purpose [20]. Surprisingly, deaf students reported moderate average use of computer for preparing assignment and presentations. Likewise, male and female students, as well as deaf students majoring in Applied Sociology, recorded moderate average wiliness to use computer whenever possible.

The results of the study confirm a significant difference 
between male and female, or between deaf students majoring in Special Education program and students majoring in Applied Sociology. The differences are significant among these students in using the computer as a thinking tool, for problem-solving, and the ability to use software related to the courses. It seems that male deaf students are more likely to use a computer than female deaf students for educational purpose, which could be related to the issue of affordability, kills, and time factors. Similarly, students majoring in the Special Education appeared to have better use of computer than did the students of the Applied Sociology. These results indicate the impact of gender and major on computer use among deaf students.

In line with prior studies [10], high use of the Internet for educational purpose is reported for self-learning or teaching, accessing information related to the programs, improving thinking skills, and for improving knowledge. The results reflect the importance of the Internet for deaf students. This is because the Internet access and use is no longer a luxury or optional, but a necessity and essential source for students to succeed in academic activities.

The results of Independent t-test confirm significant difference among students in using the Internet for accessing information, to upload files and assignments, and to improve knowledge. These findings indicate that male deaf students are more likely to use the Internet than female deaf students are. Moreover, students majoring in Special Education appeared to use the Internet more frequently than the students of Applied Sociology did. The results support the stated two hypotheses and suggest the impact of gender and academic major on deaf students use of the Internet. The differences among these students might be linked to the level of computer and the Internet skills they have. Another possibility is the role of instructors in promoting the use of computer and the Internet among deaf students. Future studies may investigate factors affecting computer and Internet use among deaf students.

\section{Conclusions}

Educational technology, such as the computer, the Internet, and other emerging technologies have become a necessity and not a luxury for university students, and deaf students are no exception. Deaf students use the computer for improving language skills, for enhancing writing skills, and for improving thinking skills. Likewise, they use the Internet as a tool for self-learning or teaching, accessing information, and improving knowledge. Therefore, academic universities and colleges should ensure that deaf students have access to a computer and the Internet on the campus. Moreover, these institutions should also organize training and workshops for deaf students on how to use effectively computer and the Internet for educational activities. Although this study has reported the use of computer and the Internet among deaf students.
It was beyond the scope of this study to investigate the level of computer skills and Internet skills of participants. With the use of recognized standards for computer skills and Internet skills, future studies could be conducted among AAU deaf students to determine the level of computer skills and Internet skills among these students. Decision-makers may use the findings of such studies in providing computer and Internet training for deaf students.

\section{REFERENCES}

[1] N. Solomon. Design and production of teaching aids. Amman, Jordan: Dar Al Safa, 2002

[2] S. I. Belson. Technology for exceptional learners: choosing instructional tools to meet students' needs. Boston: Houghton Mifflin, 2003

[3] M. Male. Technology for inclusion: Meeting the special needs of all students (4th ed.) Boston: Allyn \& Bacon, 2003.

[4] L. L. Jones, J. R. MacArthur, S. Akaygün. Using technology to engage preservice elementary teachers in learning about scientific inquiry. Center for Educational Policy Studies Journal, 1(1), 113-131, 2011.

[5] W. L. Heward. Exceptional children: an introduction to special education (8th ed.). Upper Saddle River, NJ: Prentice-Hall, 2006.

[6] M. Q. Hilat. The relationship between creative self-efficacy and supra-cognitive thinking among female students of the professional diploma in teaching at Abu Dhabi University. International Journal of Educational Research, 41, 245-279, 2017.

[7] United Nations. Convention on the rights of persons with disabilities. Conference of States Parties to the Convention on the Rights of Persons with Disabilities, session Fifth, New York, 2012. Available at: https://www.un.org/disabilit ies/documents/convention/convention_accessible_pdf.pdf

[8] M. A. Alghawi. Gifted education in the United Arab Emirates. Cogent Education, 4(1), 1-18, 2017. Online available from https://doi.org/10.1080/2331186X.2017.136 8891

[9] N. H. Hassoon, M. Othman, H. N. Abed. Evaluation on the LMS for deaf and mute students for education purpose : a case study of Amal Institution in Iraq. Paper presented at the 2nd National Graduate Conference, Universiti Tenaga National, Malaysia, 18-19, 2014.

[10] A. Kaba, Z. K. Ellala. Digital information resources: use and perceptions of deaf and hearing students. Digital Library Perspectives, 35(3-4), 227-243, 2019. Online available from https://doi.org/10.1108/DLP-05-2019-0020

[11] L. Wauters, E. Dirks. Interactive reading with young deaf and hardof-hearing children in ebooks versus print books. Journal of Deaf Studies and Deaf Education, 22 (2), 243-252, 2017. Online available from https://doi: 10.1093/deafed/en w097.

[12] D. Pilling, P. Barrett. Text communication preferences of 
deaf people in the United Kingdom. Journal of Deaf Studies and Deaf Education, 13 (1), 92-103, 2008. Online available from https://doi: 10.1093/deafed/enm034.

[13] A. Barak, Y. Sadovsky. Internet use and personal empowerment of hearing-impaired Adolescents. Computers in Human Behavior, 24, 1802-1815, 2008. Online available from https://doi: 10.1016/j.chb.2008.02.007.

[14] K. A. Peddie, R. J. Kelly-Campbell. How people with hearing impairment in New Zealand use the Internet to obtain information about their hearing health. Computers in Human Behavior, 73, 141-151, 2017. Online available from https://doi: 10.1016/J.CHB.2017.03.037.

[15] Y. Al-Hilawani. Cognitive behaviour modification: a technique for teaching subtraction skills o hearing and deaf/hard-of-hearing elementary students. International Journal of Rehabilitation Research, (23), 217-225, 2000. Online available from https://doi.org/10.1097/00004356-20 0023030-00012

[16] L. Al-Gazali, B. R. Ali. Mutations of a country: a mutation review of single gene disorders in the United Arab Emirates (UAE). Human Mutation, 31(5), 505-520, 2010. Online available from https://doi.org/10.1002/humu.21232

[17] Z. K. Ellala, E. Zaiton. Behavioural characteristics of gifted students in the sixth to ninth grades in $\mathrm{Al}$ Ain. International
Journal of Education Economics and Development, 10 (1), 36-56, 2019. Online available from https:/doi: 10.1504/IJEED.2019.097133.

[18] A. Shaqur. The reality of employing technological innovations and their constraints in schools in the West Bank and Gaza Strip from the teachers' perspective, An-Najah University Journal for Research "Humanities", 27(2), 383-416, 2013. Online available from https://journals.najah. edu/media/journals/full_texts/5_0.pdf (Arabic).

[19] S. Hanifa. The reality of using the Internet in scientific research and communication among professors, Journal of Humanities and Social Sciences, 383-400. Online available from http://revues.univ-ouargla.dz/images/banners/ASTimages/S socialesimages/SOCN05/SSP0328.pdf (Arabic)

[20] M. Maiorana-Basas and C. M. Pagliaro. Technology use among adults who are deaf and hard of hearing: a national survey, Journal of Deaf Studies and Deaf Education, 19 (3), 2014. Online available from doi: 10.1093/deafed/enu005.

[21] L. Incikabi. Teaching History of Mathematics through Digital Stories: A Technology Integration Model. In Keengwe, J. (Eds.), Handbook of Research on Educational Technology Integration and Active Learning, 162-176. Hershey, PA: IGI Global, 2015. http://doi:10.4018/978-1-4 666-8363-1.ch008 